\title{
WOMEN'S ORGANIZING AND LEADERSHIP IN REBUILDING AFGHANISTAN
}

Homa Sabri

National Programme Advisor UNIFEM Countrv Programme, Afghanistan

\section{BACKGROUND: The Women of Afghanistan}

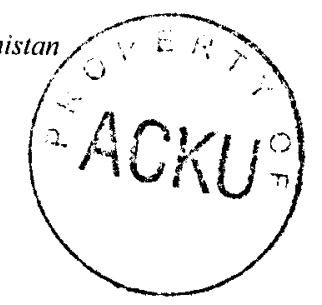

Afghanistan became the focus of world attention in late 2001 when the United States led a campaign to oust the Taleban and, subsequently, the international development community launched a peace and reconstruction movement which has been gaining grounds and re-creating hopes for many, particularly the women population who suffered much from the 23 years of war in my country.

As in most countries of the world, women comprise nearly one half of our population. Many believe that there are more women than men in Afghanistan as we lost many of our men to 23 years of armed conflict. The history, or "her story" of women's organizing in Afghanistan may be understood in the context of natural, social, cultural and political factors that somehow conspired to promote divisiveness among our people. The country's geographic terrain, which isolate communities from each other, the multiple ethnic groupings, the harsh climatic conditions, absence of communication, lack of roads connecting communities with each other, and many other factors have prevented the growth of unity and social cohesion among our people, including our women population.

Thus, it is not possible to describe in one general term the growth of women's organizing and leadership in nation building because they evolved under very diverse circumstances and context. For the women of Afghanistan, the impetus to reach out and forge solidarity with each other was born out of a desire to rise above the harsh conditions in life that plagued them, such as loss of relatives, social dislocation, absence of peace, poverty and the harsh natural environment.

Afghanistan is a traditional Muslim society. The growth of women's organizing may be viewed from the perspective of socio-cultural, economic and political conditions in which they live. They could be classified into four, namely: (a) women in the Capital City of Kabul; (b) women in the provincial urban centers; (c) women in the villages; and (d) the nomadic women.

The first three categories are not mutually exclusive. For example, there are women in some sectors of the Capital City of Kabul whose daily activities are exactly similar to the activities of women in the two other categories. However, the presence of amenities, opportunities, cultural pressures and other factors either alleviate or increase the burdens in the performance of their roles. In the Capital City where educational and employment opportunities are available for women, they tend to step from one role to another as wife, mother, professional, and housekeeper. In terms of economic roles, many women in 
Kabul are university graduates and some are working as government employees. The urban women in the provinces do embroidery in the confines of their homes but are able to travel to the bazaar to market her produce. Those in the northern region weave rugs in the seclusion of their walled compounds. The village women in the central mountains of Afghanistan take part in agricultural tasks. The nomadic women in the southern desert are engaged in the preparation of dairy products and a vast range of other women contribute to economic production in innumerable ways. One thing in common, no matter where they are or what their income earning activities are, is that all of them are responsible for housework and caring of family members.

\section{ORGANIZING AND LEADERSHIP OF WOMEN: Then and Now}

Afghan women have always maintained a positive spirit. It is surprising how they were able to do so in the midst of harsh realities within which they live. But this positive spirit is probably the single most powerful factor that moved them to reach out to each other, bind together, and collectively seek alternative solutions to the difficulties that they experience along with their families. They may be viewed as subordinate and weak, but the positive spirit moves them to keep doing good for others which unleashed their hidden courage and inner strength.

\section{The pre-Taleban era (1940 to 1996)}

Women's organizing has been spontaneous and sporadic, veering towards diverse focus, depending on what they consider as crucial to the community where they operate. The initial wave of women's organizing in the country came during peace time. While the Afghanistan was enjoying peace and security, poverty and lack of education has been pervasive and has been adversely affecting the lives of women and children in the country. Cognizant of this, the elite groups of women voluntarily came out and organized to create facilities and services to help women in need.

The first organizing initiative of women was the establishment of Afghan Women's Association, a semi-government organization that was formed by the royal elites. The association had a strong advocacy base on women's human rights with focus on the enhancement of women's knowledge and skills through vocational trainings, education for married women, and welfare assistance to the ultra poor and neediest women.

The concept of NGOs was introduced among women after the 1990's, during which time, political instability had started to sweep Afghanistan. In this period, educated Afghans gradually flee to the neighboring and western countries. The changes imposed by proRussian government on the status of women constituted a great blunder. It placed enormous complications on the recognition of women's status in a traditional Muslim society. Women's issues remained in the center of politics and interests of different political and religious groups, conflicting with women's own concept of their own space 
regions led to a gathering of some 60 provincial representatives in Kabul on 8 March 2002 .

Women picked the opportunities offered by the Bonn Peace Agreement to participate actively in the national peace and reconstruction efforts of the country. Afghan women managed to demonstrate their skills, potentials and capabilities by effectively and actively participating as peace negotiators, leaders and decision makers at every level. The following are examples of these:

a) participation of Afghan women in the Bonn Peace Conference and negotiation process;

b) holding of civil society forum;

c) participation of a woman in the recent presidential election;

d) selection of woman Chairperson in the Emergency Loya Jirga;

e) election of woman Vice-Chair and Secretaries in Constitutional Loya Jirga;

f) participation of women delegates in Constitutional Loya Jirga (not only as elected members on behalf of women, but as elected representative of their community in this very high profile gathering of national elders;

g) chairing of the Afghanistan High Commission on Human Rights;

h) participation of 40 percent of women in the recent Presidential Election;

i) establishment of Ministry of Women's Affairs headed by a woman minister; and

j) appointment of other women ministers and women deputy ministers which serve as viable resources to champion the agenda of women at the policy level and pave the ground for their engagement in the rebuilding process.

Women's participation in electoral politics and public life are among the major provisions of the Berlin plan of action, otherwise known as "The Way Ahead" Workplan of the Afghanistan Government". This document explicitly provides that the participation of women as voters and candidates in the elections shall be promoted and that the government will endeavor to increase their representation in the civil service. The current Priority Reform and Restructuring Programme of the Independent Administrative Reform and Civil Service Commission opens a fresh avenue for asserting women's participation and leadership in public life. The forthcoming Parliamentary elections is another potent vehicle, particularly as the Ministry of Women's Affairs has proactively started a process of dialoguing with electoral parties on how they will address women's concerns in their respective political agenda. 
in society. One of the major implications on women's life was seclusion of women which pushed them back to their traditional role as housewife for more than two decades.

Owing to the gradual displacement and immigration of organizers of the association the agenda of women emancipation also took a different shape. However, these elites after settlement in abroad remained as niches for networking, bringing up the concerns of women at international arena and provided financial support to NGOs in order to assist the women refuges in Pakistan, Iran and also in Afghanistan through their western allies and the donor community and international agencies.

Since Afghan women have not been exposed to NGO concept prior to conflict, it was their first challenge and opportunity to organize themselves as social workers, teachers, and advocates of human rights. They proved that they are capable of functioning as partners of men while in crises and in exile. From 1990 onwards, when political conflict and violation of women rights reached its peak, majority of women NGOs established themselves in Pakistan and Iran individually and collectively, networked nationally and internationally with Afghan women's groups, donor communities and international humanitarian aid organizations. Much attention was paid on the status of women in Islam. Skills development and welfare assistance to the needy widow refugees, educational opportunities and provision of health services were among the other focus of attention for more than two decades.

\section{Organizing and leadership during the rule of Taleban (1997-2000)}

The second wave of women's organizing came shortly after the onset of Taleban rule in 1996. When war and conflict plagued the country, educated women pooled their resources together, faced the risks and threats to life, but never remained silent. They used their knowledge and skills as advocates, social workers, lawyers and income earners, particularly at a time when their household economy was collapsing. It should be noted that women own the arts, handicrafts and weaving that are famous internationally.

Although they were banned from public life during the Taleban regime, women continued to provide community support, such as underground schooling and health services, often at great personal risk. In refugee camps in Pakistan and in other countries where the Diaspora spread over for many years, there were commendable efforts to build some capacities and sustain livelihood under adverse conditions. All of these were the pillars of a strong movement of Afghan women with a critical mass of women professionals, doctors, lawyers, teachers and journalists both within and outside Afghanistan who were the pioneers of rebuilding their communities.

\section{The contemporary era (2001 to present)}

The elements of national plan for women seem to have emerged in the roundtable on "Building Afghan Women's Leadership" held in Brussels in December 2001 prior to the Bonn Peace negotiation process. Consultations held with Afghan women from different 
There are high hopes for positive changes within the policy circle and at the community level. Mechanisms have been set up under the Government National Solidarity Programme to encourage include participation of women at every stage of project implementation at community level through women shura's (community gathering) and women's fora.

\section{OPPORTUNITIES AND CHALLENGES}

The adoption of the new Constitution which guarantees equality of between women and men in rights and responsibilities is a landmark achievement upon which continuing struggle to promote women's organizing and leadership can be anchored.

However, there is a need for a clearly articulated national policy that supports women's organizing. This should explicitly define the relationships that the State wants to build with women's organizations as well as the kind of support that women's organizations could expect from the State.

The problems generated by more than two decades of armed conflict have made the environment unsafe and complicated for the promotion of women's advancement. With the imposed limitation on their mobility, risks of security, insufficient resources for skills development and capacity building opportunities, women are challenged to compete with men for opportunities with insufficient education, experience and skills. Difficult access within communities and a lifestyle that hardly provides space and time for women outside of household responsibilities, high illiteracy, early marriage, child care and lack of men's involvement in household responsibilities are also added obstacles. Given the above hindering factors in a segregated society, it is extremely unrealistic to expect a higher output in short period of time.

\section{UNIFEM'S SUPPORT TO WOMEN'S ORGANIZING AND LEADERSHIP}

Since November 2001, UNIFEM has been conducting consultations with Afghan women from Kabul, provinces and the Diaspora, the Ministry of Women's Affairs, State Minister for Women, UN and other international and national agencies. These included two consultation workshops in Brussels, which led to the Brussels Platform for Action, and the Regional Consultation in Kabul leading to the Declaration of the $8^{\text {th }}$ of March on women in Afghanistan. The ongoing consultations have resulted in the following sectors being identified as UNIFEM priority programmes in the next four years:

* A two-year programme of in-depth socio-economic needs assessment of women in Afghanistan to come up with recommendation for effective interventions on social and economic empowerment of women;

* Support to the Ministry of Women's Affairs in establishing women's centres in provinces and develop a sustainable outreach strategy to rural areas; 
* Support to the Office of the State Minister of Women to strengthen its capacity and influence;

* Building capacity of women's civil society organisations active in the legal sphere (lawyers and judges) to ensure their contribution to the process of constitutional and legal reform. Supporting the development of women NGO resource and training centres;

- A programme of gender sensitization of the media and access to information for women.

UNIFEM is also implementing institutional capacity building support to the Ministry of Women's Affairs in which a team of gender professionals from UNDP and UNIFEM are deployed on a full time basis. Among others, this team is facilitating promotion of women's participation in the implementation of the Priority Reform and Restructuring Programme of the government which means more women in the civil service. It is also launching an activity that will build networks among women in the civil service. Relatedly, the team is assisting the NGO Relations Department of the ministry to establish cooperative relations with the women NGOs. A plan of action which include sharing of expertise among NGOs has also been developed.

UNIFEM plans to build upon the deepen the achievements made so far as well as respond to new and emerging issues expected over the coming year. As part of this process UNIFEM has made its development goal in Afghanitan to "influence and support the process of reconstruction and nation building to improve women's status and restore their rights as enshrined in the Convention of the Elimination of All forms of Discrimination against Women (CEDAW) other relevant International standards". 